\title{
Judicial training in the EU: a study for the European Parliament
}

\author{
John Coughlan
}

(C) ERA 2012

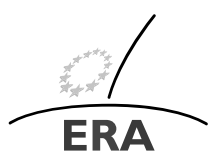

EUROPÄISCHE RECHTSAKADEMIE ACADEMY OF EUROPEAN LAW ACADEMIE DE DROIT EUROPEEN ACCADEMIA DI DIRITTO EUROPEO

TRIER - TREVES - TREVIRI

Abstract A detailed study prepared for the European Parliament by ERA and EJTN in 2011 reveals how well judges, prosecutors and court staff in the EU Member States know and make use of European law in their daily practice and analyses both the shortcomings and examples of best practice in the provision of judicial training, with a focus on training in European law.

Keywords Judiciary · Judicial training · European Union · EU law · Study

\section{Aims and content of the study}

In the course of 2011, the Academy of European Law (ERA), with the support of the European Judicial Training Network (EJTN), produced a major study for the European Parliament on the state of judicial training in the European Union at both European and national levels. ${ }^{1}$ The study focused on training in EU law but also analysed other aspects, such as the conditions under which training is provided, the methodologies used and the target groups addressed.

\footnotetext{
1 "Judicial Training in the European Union Member States", John Coughlan, Jaroslav Opravil and Wolfgang Heusel, published by the European Parliament, October 2011 (www.europarl.europa.eu/delegations/ en/studiesdownload.html?languageDocument=EN\&file=60091).
}

J. Coughlan, Deputy Director, Director of Communications ( $\varangle$ ) Academy of European Law, Metzer Allee 4, 54295 Trier, Germany e-mail: jcoughlan@era.int 
While the importance of judicial training for the effective application of EU law has been repeatedly emphasised in recent years by the European Parliament, ${ }^{2}$ the European Council $^{3}$ and the European Commission, ${ }^{4}$ no exhaustive study had been conducted on the existing provision of judicial training in the Member States. For EU action in the field of judicial training to be effective, it must take into account the reality of judges' and prosecutors' work and overcome the obstacles impeding their participation in judicial training programmes. The European Parliament therefore launched an open call for tenders, which was won by ERA in a consortium with EJTN.

The aims of the study were threefold:

- To map the current provision of judicial training in the EU in terms of the schools and institutions responsible for training;

- To compile an inventory of best practices in judicial training, especially with regard to EU law, which may be shared between jurisdictions;

- To make recommendations about possible solutions to shortcomings identified in the current provision of judicial training at EU level.

A research team was established at ERA and its work was supported by a research advisory committee,${ }^{5}$ composed of high-ranking representatives of the judiciary, and an expert evaluation group, ${ }^{6}$ bringing together experienced judicial training professionals from the Member States. The resulting study, which runs to more than 800 pages and covers all 27 EU Member States, describes the training provision for professional judges (including administrative judges), public prosecutors (including in jurisdictions where they are regarded as separate from the judiciary) as well as court staff who have legal training and who help prepare judgments, make preliminary judicial decisions or play a role in judicial cooperation. While the effective application of EU law undoubtedly also depends on the extent to which lawyers in private practice are aware of and receive training on EU law, it was decided for practical reasons not to cover the training of legal counsel in this study.

The study contains three main sections:

- Profiles of the judicial training actors at EU level, including organisations specifically established to provide judicial training, organisations that train judges and

\footnotetext{
${ }^{2}$ Notably in its Report on the role of the national judge in the European judicial system (INI/2007/2027, rapporteur Diana Wallis, adopted on 9 July 2008), its Resolution on the Stockholm Programme (B70155/2009, rapporteurs Luigi Berlinguer, Juan Fernando López Aguilar, Carlo Casini, adopted on 25 November 2009), its Report on the implementation of the Stockholm Programme in Civil Matters (2010/2080(INI), rapporteur Luigi Berlinguer, adopted on 24 September 2009) and its most recent Resolution on judicial training (2012/2575(RSP), adopted on 14 March 2012).

${ }^{3}$ The Stockholm Programme: An Open and Secure Europe Serving the Citizen (EC) No (2010/C 115/1).

4"Building trust in EU-wide justice: a new dimension to European judicial training", COM (2011) 511, 13 September 2011.

${ }^{5}$ Josef Azizi, Miguel Carmona Ruano, Nial Fennelly, Victor Hall, Pauliine Koskelo, Luís Silva Pereira, Pál Solt, Maja Tratnik, Ruud R. Winter.

${ }^{6}$ Märit Bergendahl, David Dickson, Gianluca Grasso, Victor Hall, Wolfgang Heusel, Rainer Hornung, Bettina Maurer-Kober, Eric Minnegheer, Wojciech Postulski, Luís Silva Pereira, Isabel Tomás García, Heinrich Zens.
} 
prosecutors in addition to their core activities and associations of judges that provide training to their members;

- Profiles of the judicial training actors at national level in all 27 Member States of the European Union, including details of how judicial training is organised in each Member State, the staffing and budgetary resources devoted to it, the numbers of judges, prosecutors and court staff trained each year and other key information;

- The results of a survey in which almost 6,000 individual judges and prosecutors and more than 1,000 other court officials from all EU Member States reported on their knowledge and experience of dealing with EU law, their contacts with foreign judicial authorities, their evaluation of judicial training provision, and other key factors in the creation of a common European judicial culture.

At the core of the study is a comparative assessment of the information and data gathered, richly illustrated by direct quotations from individual judges and prosecutors who participated in the survey, resulting in a series of recommendations addressed to the EU, the Member States and judicial training actors at European and national levels on how to promote best practice and solve existing shortcomings in the provision of judicial training.

\section{Survey of judges' and prosecutors' experience of judicial training}

The survey of individual judges and prosecutors was the most ambitious element of the study for the research team but the effort produced valuable and revealing results. It was essential for the quality of the study that responses were obtained from all EU Member States. It was equally important that these responses be as representative as possible of the views of judges and prosecutors across the EU by securing a common minimum response rate from all Member States. In order to achieve this, the research team adopted a distinct distribution strategy for each Member State aimed at ensuring the highest possible response rate: in some countries the questionnaire was distributed by the Ministry of Justice, in others by the High Council for the Judiciary, in others by the institution responsible for judicial training, and in two cases directly to courts and individual judges and prosecutors. By "delegating" the distribution of the survey to national institutions, the research team also ensured that it was "at arms' length" from the respondents, which it regarded as crucial given the role of the study consortium (ERA and EJTN) as judicial training actors at EU level.

The survey was conducted online in 20 different languages between late March and early May 2011. After an extension to allow for countries with a low response rate to catch up, only in one Member State (Greece) was the response rate so low as to be inadequate for the evaluation of the results. Almost all questions were in multiple-choice form. Answers to a handful of open questions were all translated into English. The research team initially set a target of over 4,500 responses, representing a sample of $4 \%$ of all professional judges and public prosecutors across the EU. It in fact received over 7,000 responses in total, with just over 6,000 from judges and prosecutors (incl. trainees)-representing $5 \%$ of all judges and prosecutors in the EU-and the remainder from court staff. 


\section{Judges' and prosecutors' knowledge of EU law}

The survey findings paint a mixed picture of judges' and prosecutors' awareness of EU law, with variations not so much according to geographical origin, but rather according to the area of law or the place in the justice system in which the respondents worked. On the one hand, for example, the battle to persuade judges of the relevance of EU law for their work seems largely to have been won: $73 \%$ of judges who responded said that EU law was very relevant to their judicial functions or relevant to some extent. On the other hand, that number was lower among prosecutors $(57 \%)$ and much lower among court staff ( $44 \%$ ), even though in all three groups a significant majority reported that the number of cases involving EU law had increased over the years: $76 \%$ of judges, $73 \%$ of prosecutors and $69 \%$ of court staff.

Recognition of the relevance of EU law is naturally influenced by the frequency with which judges, prosecutors and court staff deal with (or realise that they are dealing with) issues of EU law. $47 \%$ of judges said that they dealt with issues of EU law at least once every three months, whereas only $35 \%$ of prosecutors and $36 \%$ of court staff said the same. The frequency with which EU law issues arise also depends on the area of law in which a judge is specialised: for example, $69 \%$ of judges dealing with administrative cases reported that they dealt with EU law issues at least once every three months but only $34 \%$ of judges dealing with criminal law cases did so.

Even when judges recognise the relevance of EU law, many still lack the specific knowledge of how and when to apply it. As many as $32 \%$ of judges who responded to the survey said that they knew only to a minor extent-or even not at all—when to apply EU law directly and only $20 \%$ said they knew very well when to do so. There was no significant difference between old (pre-2004) and new Member States in this regard. The level of knowledge improves as one ascends the judicial hierarchy, but even among judges at higher or supreme instances only $31 \%$ said that they had a very good knowledge of when to apply EU law directly, while $16 \%$ said that they knew only to a minor extent when to do so and $1 \%$ said they had no knowledge at all.

Regarding the possibility - or obligation - to refer a question to the European Court of Justice for a preliminary ruling, as many as $40 \%$ of respondents said that they knew only to a minor extent — or not at all—when to do so and an even higher number-60\%—-said that they knew only to a minor extent—or not at all-how to do so. Fortunately the higher the respondents sit in the judicial hierarchy, the better their knowledge of the preliminary reference procedure, but still $20 \%$ of higher instance judges or supreme instance judges (who have an obligation to refer such questions) said that their knowledge of when to do so was minor or non-existent.

Respondents to the survey who indicated that they dealt with issues of EU law were asked if they had received any support in finding out or understanding the applicable law and, if so, from which source. Online EU databases were the third most frequently cited source of support following law books or journals and online national databases. Use of such databases varies considerably across the EU, however. The European Judicial Networks were used as a source of support by significantly fewer respondents and awareness of them generally is relatively low. $55 \%$ of judges who dealt with civil, commercial or family cases said they were unaware of the European Judicial Network in Civil and Commercial Matters. Among judges who dealt 
with criminal cases, $74 \%$ said they were unaware of the European Judicial Network in Criminal Matters and $62 \%$ said they were unaware of Eurojust. The awareness of these institutions was much better among prosecutors, however, with only $45 \%$ saying they were unaware of EJN Criminal and just $19 \%$ saying they were unaware of Eurojust.

\section{Judicial training provision in the EU}

For the purpose of the study, the national bodies responsible for judicial training were asked to describe how such training, in particular EU law training, is organised and the individual survey respondents were asked to report on their experience of it. It emerged that virtually all new entrants to the profession of judge or prosecutors today have studied EU law as part of their law degree: $94 \%$ of respondents under the age of 30 years said they had studied EU law, while $90 \%$ said they had studied the European Convention on Human Rights and as many as $77 \%$ said they had studied the law of another Member State. There is, however, a stark contrast with older generations, with almost $70 \%$ of respondents over the age of 50 saying they had not studied any of these subjects as part of their law degree.

The same generational trend can be observed in terms of the coverage of EU law in initial judicial training: while "initial training" means different things in different countries, the older you are the less likely that EU law training was part of it.

Judges have slightly more access to continuous training in general than prosecutors, who in turn have more access than court staff: $83 \%$ of judges who responded to the survey had received continuous training on a subject other than EU law, compared to $76 \%$ of prosecutors and $63 \%$ of court staff. The same trend applies to continuous training in EU or other Member States' law, which had been attended by $58 \%$ of judges who responded to the survey, $44 \%$ of prosecutors and just $23 \%$ of court staff.

These figures indicate that judges, prosecutors and court staff are all less likely to have received continuous training in EU law than in other subjects. Furthermore, their training in EU law is less likely to be up-to-date: of those judges and prosecutors who had received continuous training in EU law, only $39 \%$ said it had taken place during the last year and $27 \%$ said that it had taken place more than four years ago (thus not up-to-date with the changes brought by the Lisbon Treaty). Among judges and prosecutors who had received continuous training on other subjects, $72 \%$ said it had taken place during the last year and only $9 \%$ said it had taken place more than four years ago.

The bulk of continuous training in EU law is conducted at national level by national judicial training institutes $(21 \%$ of judges and prosecutors who responded to the survey had received continuous training in EU law from their national judicial training institute), courts and prosecutions services (12\%), councils of the judiciary $(11 \%)$ and others (8\% from ministries, $6 \%$ from universities, $4 \%$ from local or regional judicial training institutes, $1 \%$ from private companies). This is commensurate with the role of the respective training providers in the provision of continuous training in other subjects as well.

Only $14 \%$ of the judges and prosecutors surveyed said that they had received continuous training in EU law from a European training institute $(10 \%)$ and/or the 
judicial training institute of another Member State (5\%). In contrast, just $1 \%$ of court staff had attended a training programme outside their own country. Respondents were asked to indicate, if they had attended a European training programme, which institution had provided it. Rather than present a multiple-choice list, as in most of the rest of the survey, respondents were requested to fill in the name of the training provider in order to gain as complete a picture as possible of training provision at European level. As a result, however, it should be assumed that the numbers who made the extra effort to fill in this section of the survey under-represent the percentage who had actually attended a European judicial training programme. Of those who completed this section:

- By far the most had participated in continuous training offered by the Academy of European Law (ERA, $7 \%$ of all respondents to the survey) or in an exchange or training programme organised in the framework of the European Judicial Training Network (EJTN, $6 \%$ ).

- Participation in activities organised by the national judicial training bodies of other Member States constituted the next most frequently cited form of European judicial training programme, with approximately $1 \%$ of respondents from other countries having attended programmes offered by the French, Spanish or Italian judicial training institutions respectively.

- Between $0.2 \%$ and $0.6 \%$ of respondents had attended conferences or training programmes organised by EU bodies such as Eurojust, the European Judicial Networks, the European Court of Justice, OLAF and the Office for Harmonization in the Internal Market.

- Other training providers were each cited by fewer than $0.5 \%$ of respondents: e.g. the European Institute for Public Administration (EIPA, $0.4 \%$ ), the European University Institute $(0.03 \%)$ and the College of Europe $(0.02 \%)$.

\section{Shortcomings and obstacles to judicial training in EU law}

Respondents to the survey who had received continuous training (both on EU law and on other subjects) were asked for their evaluation of it. Those who had not received continuous training were asked to indicate why. All respondents were asked to make suggestions for the improvement of judicial training provision, particularly in EU law. The feedback received from this combination of questions reveals a series of obstacles to the participation of judges, prosecutors and court staff in training which must be taken into account in any attempt to increase the numbers receiving such training.

$42 \%$ of judges who participated in the survey, $56 \%$ of prosecutors and $77 \%$ of court staff said that they had not received continuous training in EU law. Among judges and prosecutors, the most frequent reason for being unable to participate in training programmes (given by $32 \%$ of judges and prosecutors who had not received training in EU law) was "No time". More specifically, their workload does not allow the necessary time for training.

After "No time", the next most frequently cited reason among judges and prosecutors for not having participated in continuous judicial training programmes on 
EU law was "No such training available": $31 \%$ of judges and prosecutors who had not attended an EU law training programme gave this explanation, while $51 \%$ of court staff said the same. While the profiles of EU and national judicial training actors demonstrate that, on the contrary, such training is indeed available - at least for judges and prosecutors-it is clear that not all have access to it. Analysis of the detailed comments made by survey respondents reveals that there are several different explanations for this, e.g. lack of information about what is on offer or restrictions related to the number of places available.

The main obstacles to increasing participation in judicial training, in particular on EU law, can be summarised as follows:

- Workload: The organisation of the justice system inhibits participation in training because the caseload of training participants is not reduced and they are not replaced during their absence;

- Lack of information: Whether more or less intentionally, in many Member States information about training programmes does not reach many judges, prosecutors and court staff;

- Short notice: Plenty of notice is required in order to adapt court hearing schedules to allow for training - this is particularly lacking for European programmes;

- Lack of places: Many survey respondents complained that there were simply not enough places available, particularly for judicial exchanges, or that they were restricted to a select few;

- Lack of funding: In some Member States participants' employers do not cover all or even part of the costs of training, in particular European training programmes;

- Institutional opposition: Whether out of understandable work management concerns, or out of scepticism as to the value of the training, superiors sometimes discourage participation in training;

- Work/life balance: Issues of work-life balance constitute a growing obstacle for participation in training that requires several days' absence from the family;

- Language barriers: Even if all other obstacles could be removed, many judges, prosecutors and court staff feel that they do not have the linguistic skills to participate in training in another language.

\section{Suggestions for improvement of judicial training in EU law}

Respondents to the survey were asked to give examples of what they considered best practice in judicial training, particularly in the field of EU law, and to make suggestions for improving and increasing participation in judicial training. The measures they proposed address diverse aspects of training, in particular continuous training, from the format and methodology to the venue, timing and funding arrangements. Responsibility for implementing such measures lies with a number of different actors, mostly within the Member States' national judicial systems, and only a handful can be achieved through direct action by the European Union. The EU can, however, encourage and enable - through its funding programmes and other direct actionsthe adoption of best practice and improvements in the provision of judicial training that would overcome the obstacles and shortcomings described above. 
The measures proposed by judges, prosecutors and court staff in answer to the survey can be grouped into the following categories:

- Ensure that training is integral to work as a judge or prosecutor:

- Adapt judges' and prosecutors' workloads to allow for training;

- Set aside (compulsory) time for training;

- Replace judges, prosecutors and court staff who are on training;

- Recognise and reward participation in training;

- Provide sufficient funding for staff to attend training.

- Make training more efficient in terms of the time and resources used:

- Improve communication about training programmes;

- Provide more decentralised training at more convenient times;

- Make better use of e-learning and videoconferencing;

- Combine decentralised and EU-level continuous training;

- Repeat training programmes;

- Train multipliers and share/re-use training materials.

- Make training more practical:

- Design training according to the needs of participants;

- Use case studies and more active forms of training;

- Offer internships at the EU courts and other institutions;

- Ensure follow-up to training in daily practice.

- Widen access to training:

- Provide more language training and multilingual training;

- Offer training to neglected professional groups, e.g. court staff;

- Ensure respect for work/life balance.

\section{Conclusions about EU support for judicial training}

The study suggests that the appetite for more EU action in the field of judicial training is high: $89 \%$ of respondents to the survey said they would appreciate measures to promote more contact with judges and/or prosecutors from other Member States, with $54 \%$ supporting more joint training, $56 \%$ supporting more exchanges and $47 \%$ expressing interest in an online database or directory. However, many of the measures proposed to improve judicial training and to increase the participation of judges, prosecutors and court staff in training programmes can only be implemented by the Member States or indeed their independent judiciaries. While the scope for direct action by the EU itself is therefore limited to a number of specific fields, it can play a supporting and enabling role in many others.

The EU's most important and effective lever with regard to judicial training is its funding programmes. Perhaps unsurprisingly, "more EU funding" was most frequently identified by national judicial training actors as the best way to improve and increase participation in judicial training in EU law. Among those that had received EU funding, however, the cumbersome application process was the most criticised aspect of the experience. Indeed, the most frequent reason for national judicial training actors not receiving EU funding was the cumbersome procedures. After "more 
funding", simplifying the procedure for EU funding was the next most frequently suggested recommendation for future EU action.

Most EU funding programmes for judicial training currently take the form of cofinancing, in which the European Commission covers up to $80 \%$ or even $90 \%$ of the costs and the training provider the remainder. Even then, the requirement on the funding recipient to make this contribution can be problematic. On the one hand, many training providers do not control their own budgets and are unable to make funding commitments beyond the current financial year, or are facing budget cuts as part of general austerity measures. On the other hand, judges, prosecutors and court staff in most Member States are used to training at national level being provided from the public purse at no or little direct cost to them. From the employer's perspective, the cost of a judge or prosecutor attending training is composed not only of any direct costs associated with it, but also of his or her salary during the training as well as potentially replacing him or her for the duration. If an EU-funded training programme is being run by a European-level training provider, asking the participant or the employer to contribute the remaining $20 \%$ of the costs through a participation fee is therefore a major obstacle to participation.

The study also revealed both a lack of awareness about specific issues of EU law and a lack of information about the judicial training programmes available. The EU could do more to address both these problems. Online EU databases already represent one of the most important sources of support for judges and prosecutors in applying EU law. They are nevertheless still relatively under-used and unknown. Awareness of the European Judicial Networks in Criminal and in Civil and Commercial Matters, as well as agencies such as Eurojust, even among judges and prosecutors specialised in the respective areas of law, is sometimes worryingly low. This is in spite of the valuable work done by them and their potential to act as a relay between judicial practitioners and the EU institutions. And while no respondent to the survey mentioned the e-Justice portal by name, giving an indication of the amount of awareness-raising that it still requires, many respondents described essentially such a service, notably in terms of providing information about the EU law training programmes available.

Finally, the study highlighted the need for the EU to reinforce its support for the existing bodies responsible for judicial training at EU level. There was no demand, either from judicial training providers or from individual respondents to the survey, for new structures in this area. There was, however, a strong desire for the existing provision to be made more accessible in terms of how it is designed, communicated and paid for and more efficient in terms of the numbers of judicial staff who are able to benefit from it.

The results of the study have already been used by the European Parliament in its Resolution of 14 March 2012 and the interim results were cited by the European Commission in its Communication of 13 September 2011. 